\title{
HUBUNGAN JENIS DINDING DAN ATAP DENGAN SUHU DAN KELEMBABAN RUMAH PADA PEMUKIMAN LAHAN BASAH
}

\author{
M. Farid Abdurahman, Imam Santoso, Erminawati \\ Poltekkes Kemenkes Banjarmasin Jurusan Kesehatan Lingkungan \\ Jl. H. Mistar Cokrokusumo No.1A Banjarbaru Kalimantan Selatan 70714 \\ E-mail : faridabdurrahman14@gmail.com
}

\begin{abstract}
Relationship Between The Type of Wall and Roof With Temperature and Humidity of The House on The Wetland Settlement. The wetland settlements are swamp ecosystems including peat swamps which are affected by fresh and brackish water. One of the characteristics of wetlands has low elevation and affected by tides. The purpose of this study was to determine the relationship between the type of wall and roof with the temperature and humidity of the house in the wetland settlement in Desa Tamban Lupak Kecamatan Kapuas Kuala Kabupaten Kapuas. Research design with Cross Sectional Study. The sample in this study totaled 58 housing units. Data analysis using the Spearman -rho correlation test. Statistical test results showed the type of wall with house temperature has no relationship with the Sig. (2-tailed) $=0.439>\alpha=0.05$. The type of roof with house temperature has no relationship with the Sig. (2-tailed) $=0.204>\alpha=0.05$. The type of wall with house humidity has no relationship with the Sig. (2-tailed) $=0.767>\alpha=0.05$. The type of roof with house humidity has no relationship with the value of Sig. (2-tailed) $=0.099>\alpha$ $=0.05$. This study showed that there was no relationship between the type of wall and roof with the temperature and humidity of the house in a wetland settlement.
\end{abstract}

Keywords: Temperature; Humidity; Wetland Settlement

Abstrak: Hubungan Jenis Dinding dan Atap Denga Suhu dan Kelembaban Rumah Pada Pemukiman Lahan Basah. Pemukiman lahan basah adalah suatu ekosistem rawa termauk rawa bergambut yang dipengaruhi oleh air tawar maupun payau. Salah satu karakteristik lahan basah yaitu mempunyai elevasi rendah dan diengaruhi oleh pasang surut air laut. Tujuan penelitian ini umtuk mengetahui mengetahui hubungan jenis dinding dan atap dengan suhu dan kelembaban rumah pada pemukiman lahan basah di desa Tamban Lupak Kecamatan Kapuas Kuala Kabupaten Kapuas. Desain penelitian dengan pendekatan Cross Sectional Study. Sampel dalam penelitian ini berjumlah 58 unit rumah. Analisis data menggunakan uji korelasi Spearman -rho. Hasil uji statistik penelitian menunjukkan jenis dinding dan suhu rumah tidak memeiliki hubungan dengan nilai Sig. (2-tailed) $=0,439>\alpha=0,05$. Jenis atap dengan suhu rumah tidak memiliki hubungan dengan nilai Sig. (2-tailed) $=0,204>\alpha=0,05$. Jenis dinding dengan kelembaban rumah tidak memiliki hubungan dengan nilai Sig. (2-tailed) $=0,767>\alpha=0,05$. Jenis atap dengan kelembaban rumah tidak memiliki hubungan dengan nilai Sig. (2-tailed) =0,099> $\alpha=0,05$. Sehingga pada penelitian ini tidak terdapat hubungan antara jenis dinding dan atap dengan suu dan kelemababan pada pemukiman lahan basah.

Kata Kunci: Suhu; Kelembaban; Pemukiman Lahan Basah 


\section{PENDAHULUAN}

Dalam buku "The Lexicon Webster Dictionary" permukiman diartikan sebagai suatu keadaan atau tempat manusia dapat menetap/tinggal pada kedudukan yang tetap sehingga tercipta keluarga yang harmonis dalam kondisi yang menguntungkan [1].

Pemukiman lahan basah ialah ekosistem lahan rawa seperti rawa gambut yang pada air tawar maupun payau. Lahan basah meliputi lahan rawa-rawa, lahan gambut dan wilayah pantai. Pemukiman lahan basah mempunyai ciri-ciri unik seperti bentangan dataran rendah di wilayah pesisir, daerah dengan elevasi rendah, wilayah yang dipengaruhi oleh pasang surut air laut, daerah yang keberadaan airnya dipengaruhi oleh musim, dan wilayah yang sebagian besar ditutupi oleh gambut [2].

Rumah atau tempat tinggal ideal di Indonesia dengan iklim tropisnya, harus dapat mengatasi masalah 'perolehan panas' matahari. Agar saat siang hari, suhu dalam ruangan lebih rendah daripada suhu yang ada di luar ruangan [3].

Untuk meciptakan kenyamanan termal pada iklim tropis, usaha yang dapat dilakukan diantaranya adalah memberikan aliran udara yang cukup sehingga dapat mengurangi radiasi panas, mencegah radiasi panas yang masuk baik dari sinar matahari langsung ataupun dari permukaan dalam dan membawa panas keluar bangunan. Atap merupakan salah satu permukaan rumah yang paling banyak menerima panas [4]. Selain atap, dinding juga merupakan permukaan rumah yang paling banyak menerima panas. Di Indonesia, dinding bangunan harus dibuat dari bahan yang mampu menahan panas dengan baik dan tahan terhadap kondisi iklim yang ada, seperti air hujan dan angin kencang [5].

Suhu dan kelembaban mempunyai hubungan yang signifikan dan salah satu faktor yang sangat berpengaruh terhadap penyakit ISPA. Untuk dapat tumbuh dan berkembangbiak sebagai faktor etiologi pneumonia, virus, bakteri dan jamur sangat dipengaruhi oleh suhu dan kelembaban yang merupakan. Faktor etiologi ini dapat tumbuh dengan baik pada kondisi dan suhu serta kelembaban yang optimum. [6].

Kabupaten Kapuas merupakan salah satu kabupaten di provinsi Kalimantan Tengah dengan kawasan lahan basah. Bagian selatan dari kabupaten Kapuas merupakan daerah pantai dan rawa-rawa dengan ketinggian antara 0 - 5 meter dari permukaan air laut yang mempunyai elevasi $0 \%$ - 8\% serta dipengaruhi oleh pasang surut dan merupakan daerah yang mempunyai potensi banjir yang cukup besar [7].

Kecamatan Kapuas Kuala memiliki 13 desa dengan total luas wilayah $360,62 \mathrm{~km}^{2}$. Salah satu desa di Kecamatan Kapuas Kuala dengan angka kejadian ISPA yang tinggi dan memiliki ketinggian terendah dari permukaan laut yaitu desa Tamban Lupak dengan ketinggian hanya 1 meter dari permukaan laut. Desa Tamban Lupak memiliki luas wilayah $4,9 \mathrm{~km}^{2}$ dan merupakan pemukiman lahan basah yang dipengaruhi oleh pasang surut air laut. Banyaknya populasi membuat perumahan di desa Tamban Lupak mempunyai banyak variasi jenis dinding maupun atap [8].

Berdasarkan paparan diatas maka menarik untuk dilakukan penelitian tentang hubungan jenis dinding dan atap dengan suhu dan kelembaban rumah pada pemukiman lahan basah.

\section{BAHAN DAN CARA PENELITIAN}

Jenis penelitian ini ialah analitik dengan desain cross sectional studies. Penelitian ini dilakukan sejak bulan Oktober 2019 sampai Mei 2020. Populasi dalam penelitian ini adalah seluruh rumah yang tidak mempunyai plafon, mempunyai organisasi kamar, dan dihuni. Pengambilan sampel menggunakan teknik Simple Random Sampling dengan jumlah sampel sebanyak 58 unit rumah. Rumah yang menjadi sampel kemudian menandatangani formulir persetujuan Informed Consent.

Suhu dan kelembaban diukur dengan alat Thermohygrometer selama lebih kurang 5 menit pada pukul 19.00 - 21.00 WITA, apabila cuaca hujan maka tidak dilakukan pengukuran. 


\section{HASIL PENELITIAN DAN PEMBAHASAN}

Tabel 1. Sebaran Jumlah Jenis Dinding Rumah

\begin{tabular}{c|ccc} 
NO & JENIS DINDING & JUMLAH & PRESENTASE (\%) \\
\hline $\mathbf{1}$ & Papan & 40 & 69 \\
$\mathbf{2}$ & Kalsiboard & 4 & 6,9 \\
$\mathbf{3}$ & Bata & 4 & 6,9 \\
$\mathbf{4}$ & Beton & 10 & 17,2 \\
& & 58 & 100
\end{tabular}

Jenis dinding rumah yang paling banyak digunakan oleh masyarakat di Desa
Tamban Lupak adalah jenis dinding papan kemudian beton, kalsiboard dan bata.

Tabel 2. Sebaran Jumlah Jenis Atap Rumah

\begin{tabular}{c|ccc} 
NO & JENIS ATAP & JUMLAH & PRESENTASE (\%) \\
\hline $\mathbf{1}$ & Seng & 23 & 39,6 \\
$\mathbf{2}$ & Asbes & 23 & 39,6 \\
$\mathbf{3}$ & Genteng & 9 & 15,6 \\
$\mathbf{4}$ & Rumbia & 3 & 5,2 \\
& & 58 & 100
\end{tabular}

Masyarakat di Desa Tamban Lupak paling banyak menggunakan atap rumah jenis seng dan asbes kemudian genteng serta rumbia. Hasil pengukuran menunjukkan bahwa suhu terendah ruangan rumah di Desa Tamban Lupak yaitu $26{ }^{\circ} \mathrm{C}$ dan suhu tertinggi $30{ }^{\circ} \mathrm{C}$, sementara untuk suhu rata- ratanya yaitu $28,95 \quad{ }^{\circ} \mathrm{C}$. Sedangkan kelembaban terendah ruangan rumah di Desa Tamban Lupak yaitu $79 \%$ dan kelembaban tertinggi yaitu 95\%, sementara untuk kelembaban rata-ratanya yaitu $86,55 \%$.

Tabel 3. Sebaran Suhu Ruang Menurut Jenis Dinding

\begin{tabular}{ccccc}
\hline \multirow{2}{*}{ No. } & \multirow{2}{*}{ Jenis Dinding } & \multicolumn{2}{c}{ Suhu Ruangan } & \multirow{2}{*}{$\sum$} \\
\cline { 3 - 3 } 1 & Nilai Range & Rata-rata & 40 \\
2 & Papan & $26-30^{\circ} \mathrm{C}$ & $28,83^{\circ} \mathrm{C}$ & 4 \\
3 & Kalsiboard & $29-30^{\circ} \mathrm{C}$ & $29,5^{\circ} \mathrm{C}$ & 4 \\
4 & Bata & $29-30^{\circ} \mathrm{C}$ & $29,5^{\circ} \mathrm{C}$ & 10 \\
Sig. (2-tailed) $=0,439>\alpha=0,05$ & $28-30^{\circ} \mathrm{C}$ & $29^{\circ} \mathrm{C}$ & \\
\hline
\end{tabular}

Hasil analisis menggunakan metode uji korelasi Spearman -rho, didapatkan hasil Sig. (2-tailed) $=0,439>\alpha=0,05$ maka keputusan Ho diterima, interpretasinya secara statistik tidak ada hubungan antara jenis dinding dengan suhu dalam rumah. Secara teoritis, kondisi lingkungan yang masih bagus dari segi vegetasi berperan mempengaruhi rendahnya suhu, hal ini relevan dengan penelitian Alahudin yang meneliti tentang kenyamanan termal bangunan Tongkonan Toraja dan mendapatkan hasil 
bahwa terdapat perbedaan antara tongkonan di lingkungan yang masih bagus dengan tongkonan di lingkungan yang kurang bagus, tongkonan di lingkungan yang masih bagus memiliki temperature yang lebih rendah daripada tongkonan di

lingkungan yang kurang bagus [4]. Sehingga peneliti berpendapat bahwa jenis dinding yang digunakan pada pemukiman dengan kondisi lingkungan masih bagus tidak berpengaruh terhadap suhu rumah.

Tabel 4. Sebaran Suhu Ruang Menurut Jenis Atap

\begin{tabular}{ccccc}
\hline \multirow{2}{*}{ No } & Jenis Atap & \multicolumn{2}{c}{ Suhu Ruangan } & \multirow{2}{*}{$\sum$} \\
\cline { 3 - 3 } 1 & Seng & Nilai Range & Rata-rata & 23 \\
2 & Asbes & $27-30^{\circ} \mathrm{C}$ & $29,04^{\circ} \mathrm{C}$ & 23 \\
3 & Genteng & $27-30^{\circ} \mathrm{C}$ & $29,09^{\circ} \mathrm{C}$ & $20^{\circ} \mathrm{C}$ \\
4 & Rumbia & $26-29^{\circ} \mathrm{C}$ & $28,78^{\circ} \mathrm{C}$ & 9 \\
Sig. $(2$-tailed) $=0,204>\alpha=0,05$ & & $27,67^{\circ} \mathrm{C}$ & 3 \\
\hline
\end{tabular}

Hasil analisis menggunakan metode uji korelasi Spearman's rho, didapatkan hasil Sig. (2-tailed) $=0,204>\alpha=0,05$ maka keputusan Ho diterima, interpretasinya secara statistik tidak ada hubungan antara jenis atap dengan suhu dalam rumah. Kelembaban yang tinggi dapat menyebabkan uap air akan keluar dari mulut ketika bernapas [9]. Kelembaban di malam hari cenderung meningkat karena dipengaruhi oleh faktor suhu yang menurun. Nilai kelembaban udara berbanding terbalik dengan nilai suhu udara, suhu udara mengalami kenaikan dari pukul 06.00 pagi hingga puncaknya pukul 14.00, kemudian mengalami penurunan dari pukul 14.00 sampai dengan 06.00 pagi, sebaliknya dengan hasil pengukuran kelembaban [10]. Dari uraian tersebut, peneliti berpendapat bahwa jenis dinding yang digunakan di pemukiman lahan basah tidak mempengaruhi kelembaban ruang pada malam hari.

Tabel 5. Sebaran Kelembaban Ruang Menurut Jenis Dinding

\begin{tabular}{ccccc}
\hline \multirow{2}{*}{ No } & Jenis Dinding & \multicolumn{2}{c}{ Kelembaban Ruangan } & \multirow{2}{*}{$\sum$} \\
\cline { 3 - 4 } 1 & Papan & $79-95 \%$ & Rata-rata & 40 \\
2 & Kalsiboard & $81-90 \%$ & $86,5 \%$ & 4 \\
3 & Bata & $81-89 \%$ & $85,75 \%$ & 4 \\
4 & Beton & $79-92 \%$ & $83,5 \%$ & 10 \\
Sig. (2-tailed) $=0,767>\alpha=0,05$ & & & \\
\hline
\end{tabular}

Hasil analisis menggunakan metode uji korelasi Spearman's rho, didapatkan hasil Sig. (2-tailed) $=0,767>\alpha=0,05$ maka keputusan Ho diterima, interpretasinya secara statistik tidak ada hubungan antara jenis dinding dengan kelembaban dalam rumah. Secara teoritis suhu ruangan, selain dipengaruhi oleh kelembaban, juga dipengaruhi oleh ketinggian dari permukaan air laut, sinar matahari yang masuk ruangan, peralatan elektronik dalam ruangan, distribusi udara dalam

ruangan, keberadaan ventilasi, kepadatan hunian ruang, aktivitas yang ada di ruangan, kegiatan keluar masuk ruangan, bahan dinding, dan lantai serta atap ruangan [9]. Sehinga peneliti berpendapat bahwa jenis atap yang digunakan tidak mempunyai pengaruh terhadap suhu 
dengan elevasi rendah.

Tabel 6. Sebaran Kelembaban Ruang Menurut Jenis Atap

\begin{tabular}{ccccc}
\hline \multirow{2}{*}{ No } & Jenis Atap & \multicolumn{2}{c}{ Kelembaban Ruangan } & \\
\cline { 3 - 4 } & Seng & Nilai Range & Rata-rata & \\
1 & Asbes & $79-95 \%$ & 23 \\
2 & Genteng & $80-92 \%$ & $88,17 \%$ & 23 \\
3 & Rumbia & $81-92 \%$ & $85,43 \%$ & 9 \\
4 & & $84,89 \%$ & 3 \\
Sig. (2-tailed) $=0,099>\alpha=0,05$ & & & \\
\hline
\end{tabular}

Hasil analisis menggunakan metode uji korelasi Spearman's rho, didapatkan hasil Sig. (2-tailed) $=0,099>\alpha=0,05$ maka keputusan Ho diterima, interpretasinya secara statistik tidak ada hubungan antara jenis atap dengan kelembaban dalam rumah. Faktor-faktor yang sangat berpengaruhi terhadap suhu dan kelembaban udara diantaranya yaitu pengaruh air dan tanah, karena banyaknya jumlah uap air di dalam tanah ataupun di udara meyebabkan tingginya kelembaban. Berbagai jenis atap berpengaruh terhadap kelembaban pada dinding bangunan, desain atap juga harus mampu mencegah air hujan agar tidak membasahi dinding, selain itu atap juga harus tahan oleh cuaca. Kelembaban dalam bangunan dapat berupa uap air pada bahan bangunan [11]. Dengan demikian peneliti berpendapat bahwa jenis atap yang digunakan tidak berpengaruh terhadap kelembaban dalam rumah pada saat malam hari dan disaat musim penghujan.

\section{KESIMPULAN DAN SARAN}

Secara statistik tidak terdapat hubungan jenis dinding dan atap dengan suhu dan kelembaban rumah. Untuk mengurangi panas dan kelembaban ruangan dapat menggunakan ventilasi silang (cross ventilation) yaitu dengan cara membuat lubang ventilasi yang saling berhadapan/berseberangan di antara 2 dinding ruangan. Selain itu lubang ventilasi tersebut juga tidak boleh terhalang oleh benda seperti lemari dan sebagainya

\section{KEPUSTAKAAN}

1. Suharno FM. Penyehatan Pemukiman. Yogyakarta: Gosyen Publishing; 2011.

2. Poniman A, Nurwadjedi, Suwahyuono. Penyediaan informasi spasial lahan basah untuk mendukung pembangunan nasional. Forum Geogr [Internet] 2006;20(2):120-34.

3. Rury N, Pribadi IGOS, Santoso D. Pengaruh Material Dan Bentuk Atap Rumah Tinggal Terhadap Suhu Di Dalam Ruang the Effect of House Material and Roof Shape on Indoor Temperature. J Arsit 2015;15:52-63.

4. Alahudin M. Kenyamanan termal pada bangunan hunian bangunan Toraja (studi kasus tongkonan dengan material atap seng). J Ilm Mustek Anim Ha ISSN 2089-6697 2012;1(2):85-90.

5. Surowiyono TT. Dasar Perencanaan Rumah Tinggal. Jakarta: Pustaka Sinar Harapan; 2002.

6. Heru padmonobo, Onny Setiani TJ. Hubungan Kondisi Lingkungan Fisik Rumah Dengan Kejadian Pneumonia Pada Balita Di Wilayah Kerja Puskesmas Jatibarang Kabupaten Indramayu. J Kesehat Lingkung 
Indones 2012;11(2):194-8.

7. BPS. Kabupaten Kapuas Dalam Angka Tahun 2019 [Internet]. In: katalog. 2019. page 356.

8. BPS. Kecamatan Kapuas Kuala Dalam Angka Tahun 2018. 2018.

9. Cahyono T. Penyehatan Udara. Yogyakarta: CV. Andi Offset; 2017.

10. Tika II. Variasi Suhu Dan Kelembaban Udara Di Taman Suropati Dan Sekitarnya. 2010;2433.

11. Utomo PU, Cahyono T. Hubungan Jenis Atap Dengan Suhu dan Kelembaban Kamar Tidur di Desa Karangmangu RW 01 Kecamatan Baturraden Kabupaten Benyumas Tahun 2015. Keslingmas 2015;35:86-151. 